\title{
Early Detection of Child Development Deviation Training Program in The Context of Special Needs Children Identification
}

\author{
Febrita Ardianingsih ${ }^{\mathrm{a}}$, Siti Mahmudah ${ }^{\mathrm{b}}$ \\ Special Education Department, Faculty of Education, State University of Surabaya \\ Surabaya, Indonesia \\ Corresponding e-mail: afebritaardianingsih@unesa.ac.id, ${ }^{b}$ sitimahmudah@unesa.ac.id
}

\begin{abstract}
The teachers of Early Childhood Education almost every day interact with early childhood so that early childhood teachers need to have knowledge about child development and have the skills to detect early deviation of child development. Thus, the incidence of special needs children can be detected early and can be intervened early as well. During this time in Indonesia, early detection of child development deviation is usually done by health workers. This research aimed to know training program about early detection of child development deviations in the context of special needs children identification. This research was conducted at Early Childhood Education which is indicated to have children with special needs, that is Kindergarten Ketajen, Sidoarjo, East Java, Indonesia. The subjects of the study were all teachers in the kindergarten, a number of 11 people. This research was a descriptive research. The data were analyzed using descriptive statistic. The results of this study showed that the training program improved early childhood teachers' knowledge and skills about early detection of child development deviations in the context of special needs children identification.
\end{abstract}

Keywords: $\quad$ early detection, child development, special needs children

\section{INTRODUCTION}

The number of Children with Special Needs each year shows an increase [1]. In 2007, the Directorate of PSLB (Directorate of Special School Development) mentioned the number of Children with Special Needs in Indonesia, which was 318,600 children [2]. Based on the National Socioeconomic Survey (SUSENAS) of March 1, 2011, the number of Indonesian children was $82,980,000$. 9,957,600 of the population were children with special needs in the category of children with disabilities [3].

The increase in the number of children with special needs is not in line with inclusive education services. Based on the results of Sunardi's study in 2009, on 12 (twelve) inclusive schools in Bandung Regency and Bandung City, in general, there were five issue of inclusive education at the school level, i.e.: understanding and implementation, school policy, learning process, teacher condition, and support system [4]. More specifically, the issue of inclusive education at the level of Early Childhood Education is that many early childhood educators, as second line after parents, still have difficulty in identify special needs children with their various characteristics [5].

Early detection of child development deviations is an important step in the identification and early intervention of children with special needs. It is based on the idea that the early stages of development determine future development [6]. Good child development monitoring can detect early deviations. Early identification enables to develop interventions that may alleviate or eliminate later difficulties [7]. In other words, if deviations occur at an early age and are detected as early as possible, then intervention will produce satisfactory results, whereas if the deviations occurs at an early age but are detected at a later age, the outcome of the intervention will be less than satisfactory.

Literally, identification is finding or identifying. Identification of children with special needs is intended to determine whether a child has an abnormality (physical, intellectual, social, emotional, and/or sensory neurological) in development compared to other children of his or her normal age [8]. Each state has developed specific criteria and measurement procedures for ascertaining what constitutes a developmental delay. Many states have chosen to define a developmental delay quantitatively, using a youngster's performance on standardized developmental assessments. In one state, a child might be described as being delayed if her performance on a standardized test is at least 25 percent below the mean for children of similar chronological age in one or more developmental areas such as motor, language, or cognitive ability. In another state, the determination is made when a preschooler's score on an assessment instrument is two or more standard deviations below the mean for youngsters of the same chronological age. Each approach has its advantages and disadvantages. What is really important, however, is that the pupil be identified and receive the appropriate services [9].

Typically, early detection of child development deviations is usually done by health cadres or health workers at Posyandu or in health centers or other 
health services. While parties who often interact with early childhood, in addition to parents, are early childhood teachers. So that early childhood teachers are expected to have an understanding of the development of each student. Understanding of the development and characteristics in early childhood even become one of the indicators of the competence of early childhood teachers who must be mastered. In Law No. 14 of 2005 mentioned in article 1 verse 10 about the competence of a teacher is a set of knowledge, skills, and behaviors that must be possessed, experienced, and mastered by teachers or lecturers in performing professional duties [10]. Not enough just to the ability to organize the class, but also to the ability of an educator to understand the differences of each student, which includes their growth and development, abilities, weaknesses, and even the strength of each of their students [11].

Therefore, it is necessary to be early detection of child development deviations training program for early childhood teachers in order to identify children with special needs. The purpose of this research is to know the implementation of training program on: (1) early childhood teacher knowledge about early detection of child development deviations in the context of children with special needs identification, and (2) early childhood teacher skills in early detection of child development deviations in the context of children with special needs identification.

\section{METHOD}

The type of the study was descriptive. The data described in this study were data on the application of training program to the knowledge and skills of early childhood teachers in early detection of child development deviations as an effort to identify early children with special needs. The location of research was kindergarten that was indicated to have children with special needs, namely TK Dharma Wanita, Ketajen, Sidoarjo. The subjects of the study were all teachers in the kindergarten, which were 11 (eleven) teachers.

Data collection techniques were: (1) Observation; preliminary observation and final observation were done to get skills data of early childhood teacher during practice of early detection of child development deviations toward the students in Kindergarten Dharma Wanita Ketajen, Sidoarjo (2) Test; in the form of pretest and posttest (writing test) to get data of early childhood teacher knowledge. The instrument used in this study was an instrument developed by the research team itself through the validation stages of the expert. Data were analyzed using descriptive statistics.

\section{RESULT}

Early detection of child development deviations training program in order to identify children with special needs lasted for 1 (one) week. The training program started with pretest (written test) and continued with the lectures and discussion on child development, early detection of child development deviations, and identification of children with special needs. After that, early childhood teachers did the practice of early detection of child development deviations toward the students in Kindergarten Dharma Wanita Ketajen, Sidoarjo. Activity ended with posttest in the form of a written test.

A. Implementation of Training Programs on Early Childhood Teachers Knowledge in Early Detection of Child Development Deviations in The Context of Children with Special Needs Identification

At the beginning of the lecture and discussion sessions, most early childhood teachers still seemed passive and less enthusiastic about the activities, and most of the questions expressed by early childhood teachers were very basic about "what", "who", "when" and "where". The teacher rarely gave analysis questions. As time went by, early childhood teachers were getting enthusiastic and getting involved with the activities. Questions began to lead to applications and analysis. Even the teachers associated the topics with the events they experienced daily. The more teachers saw the connection, the more active and enthusiastic they became. All participants asked questions and even became abundant so not all questions could be answered due to schedule limitations.

The knowledge of early childhood teachers in early detection of child development deviations is shown from pretest and posttest results. The tests include knowledge of child development, early detection of child development and identification of children with special needs. The mean pretest score is 61.43. While the mean posttest value is 87.14 .

\section{B. Implementation of Training Programs on Early Childhood Teachers Skills in Early Detection of Child Development Deviations in The Context of Children with Special Needs Identification}

At the beginning of practice session, early childhood teachers were still very hesitant in performing early detection based on the available instruments, they always asked every time doing the steps. As time went by, the teachers had begun to look confident in doing early detection, they rarely asked when applying the steps. The enthusiasm and activity of the teachers could in the practice session still be maintained as high as in the lecture and discussion session. They were very excited to practice the early detection of child development that they had learned. Questions continued to flow to meet the participants' curiosity.

The skill of early childhood teachers in early detection of child development deviations, seen from 
the results of preliminary observation and final observation. Preliminary observation was performed at the beginning of practice session. The final observation was conducted at the last practice session. The practice of early detection was applied toward the students in Kindergarten Dharma Wanita Ketajen, Sidoarjo. The mean of preliminary observation value is 73.33 , and the mean of final observation value is 82.86 .

\section{DISCUSSION}

The pretest result with a mean score of 61.43 indicates that early childhood teachers do not have sufficient knowledge about early detection of child development deviations. This lack of knowledge was also evident during the early lecture and discussion sessions. Most of the questions expressed by early childhood teachers were still very basic about "what", "who", "when", and "where". They rarely provided analytical questions. Most early childhood teachers also still seemed passive and less enthusiastic to attend the training at the beginning of the lecture and discussion sessions. The low enthusiasm is due to the early childhood teachers still do not understand the importance of child development and early detection of child development deviations in the preschool. The enthusiasm and activeness of early childhood teachers increased after given understanding and some examples of real events about child development and early detection of child development deviations.

The initial skills of early childhood teachers in early detection of child development deviations are also poor. Evidenced by the mean of preliminary observation score is 73.33. During the practice session, the enthusiasm and activity of early childhood teachers were very high. Those showed that they had understood the importance of early detection of child development in early childhood.

The enthusiasm and passion of learning successfully increase the knowledge and improve the skills of early childhood teachers about early detection of child development deviations in the context of children with special needs identification. Thus, this research result in the fact that the implementation of training program can increase the knowledge and improve the skills in early detection of child development deviations in the context of children with special needs identification. This finding is evident from the increase of mean score of pretest and posttest, i.e. from 61.43 to 87.14 , and from the increase of mean score of the preliminary and final observation, i.e. from 73.33 to 82.86 .

The findings of this study concur with other research findings that training seems to make a difference [12], and teachers seem to be willing to receive training to improve their knowledge and skills and to collaborate with other people to help children with special needs $[13,14]$. Similarly, coaching and further education in special education topics may help staff to achieve higher levels of quality [15]. Reference [16] further corroborates the findings of this study, i.e. training had a significant impact on teaching efficacy for inclusive practice. In addition, the duration of this training program also matches the recommended duration of training, as in [17]-training courses ranged from a 1-week basic introductory course to a 3 -week advanced course covering all aspects of inclusion. Specific thematic courses spanning 1 to 3 weeks were also offered where the focus was on including learners with different educational needs such as Autistic Spectrum Disorder or Attention Deficit Hyperactivity Disorder.

Good knowledge and skills in the early detection of development deviations in the context of children with special needs identification is needed by early childhood teachers. Thus, early childhood teachers can find out whether the growth and development of early childhood children have abnormality or not. The identification of children with special needs in special education is conducted for five purposes, i.e.: screening, referral, classification, learning planning, and monitoring of learning progress [8]. Screening serves to mark which children show certain symptoms, then conclude which children have certain abnormalities/deviations, so classified as children with special needs. Referral is meant if there are children who need to be consulted to other professionals such as psychologist, doctor, orthopedagog, and therapist. Classification aims to determine whether a child who has been referred to a professional skill really needs further treatment or can be directly given a special education service. Learning planning means for the purpose of preparing individualized educational programs. And monitoring of learning progress is carried out to determine whether the specific learning program provided is successful or not.

Reference [7] also supports that early identification enables to develop interventions that may alleviate or eliminate later difficulties. Therefore, early childhood teachers who almost every day interact with early childhood are required to have an understanding of the development of each student and be able to recognize each type of needs required by each student [11]. The statement is in accordance with [18]-the teacher must have sufficient knowledge of the cognitive, behavioral, and social characteristics associated with these children.

A broader implication of the findings of this study is that early childhood teachers with training in special education are generally more positive about inclusion [19]. Teachers with training in special education had more positive views for children with intellectual disability, visual and hearing impairment, as well as speech and language impairment than teachers and administrators without training in special education. Similar as [20]-preschool teachers with special education training would hold more positive views about inclusion compared with their counterparts without training. Moreover, the availability of resources and in-service training of staff did seem to play a key role in the preschool education function $[15,21]$.

Although the findings of this study have contributed to the knowledge and skills of early childhood teachers in early detection of child 
development deviations, there is limitation. In fact, the participants were limited and cannot be considered representative for the entire preschool system. Instead, the study provides descriptions of examples of one preschool organization. Future research needs to have more participant numbers and have a variety of research sites.

\section{CONCLUSION}

This study describe the implementation of training program to early childhood teacher knowledge and skills in early detection of child development deviations in the context of children with special needs identification. The result indicates that: (1) the implementation of training program increase early childhood teacher knowledge in early detection of child development deviations in the context of children with special needs identification, and (2) the implementation of training program improve early childhood teacher skills in early detection of child development deviations in the context of children with special needs identification.

\section{RECOMMENDATIONS}

To advance inclusion, our findings encourage future research and practice to pursue the following strategies and investigations: (1) future research needs to have more participant numbers and have a variety of research sites, (2) future research should examine what forms of training make a difference, and (3) future research may perform at different levels of education.

\section{ACKNOWLEDGMENT}

The authors are very grateful to the head teacher and staff who have contributed to various components of the research.

\section{REFERENCES}

[1] M. Mursanib, (2013), "Meningkatkan keterampilan identifikasi anak berkebutuhan khusus bagi mahasiswa Prodi PG-PAUD FKIP Universitas Tadulako", Tri Sentra Jurnal Ilmu Pendidikan, 2, 4, pp. 20-30.

[2] Direktorat Pembinaan Sekolah Luar Biasa, Pedoman Umum Penyelenggaraan Pendidikan Inklusif, Jakarta: Depdiknas, 2007.

[3] Kementrian Pemberdayaan Perempuan dan Perlindungan Anak, Panduan Penanganan Anak Berkebutuhan Khusus Bagi Pendamping (Orang Tua, Keluarga, Dan Masyarakat), Jakarta: Kemen PPPA, 2013.

[4] Sunaryo, (2009), Manajemen Pendidikan Inklusif (Konsep, Kebijakan, dan Implementasinya dalam Perspektif Pendidikan Luar Biasa), Bandung: Jurusan PLB FIP UPI.
[5] E. Adnan, dkk, (2012), Mengenal Anak Berkebutuhan Khusus, Bahan Ajar Diklat Berjenjang: Diklat Dasar, Jakarta: Direktorat Pembinaan Pendidik Dan Tenaga Kependidikan PAUD NI Direktorat Jenderal PAUD NI Kementerian Pendidikan Dan Kebudayaan.

[6] Ikatan Dokter Anak Indonesia (IDAI) Jawa Timur, Deteksi Dini Tanda dan Gejala Penyimpangan Pertumbuhan dan Perkembangan Anak, Modul Pelatihan, Surabaya: IDAI Jawa Timur, 2010.

[7] J. Salvia, J. E. Ysseldyke, and S. Bolt, (2010), Assessment in Special and Inclusive Education, 11th ed, Belmont, CA: Wadsworth Cengage Learning,

[8] Direktorat Pembinaan Sekolah Luar Biasa, (2008), Identifikasi dan Asesmen Anak Berkebutuhan Khusus: Pedoman Khusus Pendidikan Inklusif, Jakarta: Depdiknas.

[9] R. Gargiulo, and J. Kilgo, (2011), An introduction to young children with special needs, 3rd ed., Belmont, CA: Wadsworth Cengage Learning.

[10]Undang Undang Republik Indonesia Nomor 14 Tahun 2005 tentang Guru dan Dosen.

[11] S. Wijaya, "Efektivitas pelatihan identifikasi dini keterlambatan bicara pada anak usia pra sekolah untuk meningkatkan kompetensi pedagogik guru PAUD”, Proceeding Seminar Nasional Selamatkan Generasi Bangsa dengan Membentuk Karakter Berbasis Kearifan Lokal, hal 118-126, Juni 2015.

[12] S. J., Damore, and C. Murray, (2009)“Urban elementary school teachers' perspectives regarding collaborative teaching practices," Remedial and Special Education, vol. 30, pp. 234-244.

[13] D. Haycock, and A. Smith, (2011), "To assist or not to assist? A study of teachers' views of the roles of learning support assistants in the provision of inclusive physical education in England," International Journal of Inclusive Education, vol. 15, pp. 835-849.

[14] S. Rakap, and L. Kaczmarek, (2010), "Teachers' attitudes towards inclusion in Turkey," European Journal of Special Needs Education, vol. 25, pp. 59-75.

[15] European Agency for Special Needs and Inclusive Education (European Agency), Key Principles for Promoting Quality in Inclusive Education Recommendations for Policy Makers, 2009. $<$ https://www.europeanagency.org/sites/default/fil es/key-principles-for-promoting-quality-ininclusive-education_keyprinciples-EN.pdf $>$

[16] C. Forlin, T. Loreman, and U. Sharma, (2014), 'A system-wide professional learning approach about inclusion for teachers in Hong Kong," AsiaPacific Journal of Teacher Education, vol. 42, pp. 247-260.

[17] K. F. Sin, K. W. Tsang, C. Y. Poon, and C. L. Lai, (2010), "Upskilling all mainstream teachers: What 
is viable?" Teacher Education for Inclusion: Hanging Paradigms and Innovative Approaches, pp. 236-245, Abingdon: Routledge.

[18]L. Fox, G. Dulap, M. L. Hemmeter, G. E. Joseph, and P. S. Strain, (2003), 'The teaching pyramid: a model for supporting social competence and preventing challenging behavior in young children," Young Children, vol. 58, pp. 48-52.

[19]F. L. M. Lee, D. Tracey, K. Barker, J. C. M. Fan, and A. S. Yeung, (2014), "What predicts teachers' acceptance of students with special educational needs in kindergarten?" Australian Journal of
Educational and Developmental Psychology, vol. 14, pp. 60-70.

[20]U. Sharma, C. Forlin, and T. Loreman, (2008), "Impact of training on pre-service teachers' attitudes and concerns about inclusive education and sentiments about persons with disabilities," Disability \& Society, vol. 23, pp. 773-785.

[21] OECD (Organisation for Economic Co-operation and Development). Education Policy Analysis, 2003 edition, 2003. $<$ http://www.oecd.org/edu/school/26527517.pdf $>$ 